\title{
Benign Gastric Granular Cell Tumor
}

National Cancer Institute

\section{Source}

National Cancer Institute. Benign Gastric Granular Cell Tumor. NCI Thesaurus. Code C5483.

A non-metastasizing neoplasm arising from the gastric wall. It is characterized by the presence of large polygonal cells with abundant granular cytoplasm. 